\title{
Plant Growth and Yield of Red Raspberry following Primocane Defoliation
}

\author{
D.A. Raworth and S.J. Clements \\ Agriculture and Agri-Food Canada, Pacific Agriculture Research Centre, \\ P.O. Box 1000, Agassiz, B.C.VOM 1A0, Canada
}

Additional index words. Rubus idaeus, Tetranychus urticae, yield components, winter damage

\begin{abstract}
Red raspberry (Rubus idaeus L. cv. Willamette) primocanes were artificially defoliated to various degrees and at two dates in each of 2 years to simulate defoliation caused by the twospotted spider mite (Tetranychus urticae Koch). The effect on primocane diameter, lateral length, yield and four yield components was determined. When defoliation occurred evenly along the length of the primocanes, and all floricanes and excess primocanes were removed in early Aug. 1989, yield was reduced $26 \%$ at $25 \%, 50 \%$, and $75 \%$ defoliation and $55 \%$ at $100 \%$ defoliation compared with nondefoliated controls. The number of canes per stool, number of fruit per lateral, and weight per fruit were reduced when defoliation occurred earlier, in August rather than September, but the number of laterals per cane increased with early defoliation. The effect of increasing defoliation on plant growth and yield was generally nonlinear. When defoliation occurred in sections along the lower $2 \mathrm{~m}$ of all primocanes, and all floricanes and excess primocanes were removed in Nov. 1992, no significant differences in yield or three yield components were detected. The effects of primocane defoliation are not necessarily predictable, so $T$. urticae should be controlled before mite-induced defoliation occurs.
\end{abstract}

Twospotted spider mites are a pest of concern in raspberry, but there is little conclusive evidence that they affect yield. Cameron et al. (1990) showed that plants infested with $T$. urticae in a greenhouse underwent several physiological changes that reduced photosynthesis. Defoliation and mite injury to primocanes increased the susceptibility of the bud tissues to winter injury and reduced the number of live dormant primary buds and primary laterals (Doughty et al., 1972). Winter injury was associated with late acclimation in plants defoliated prematurely (Jennings et al., 1972). However, the plant has considerable yield-regulating capacity despite the loss of various yield components such as floricanes and buds (Crandall et al., 1974; Moore, 1994; Waister and Barritt, 1980). This apparent resilience also was observed by Raworth (1989); yield from floricanes having as many as 100 mites per leaflet, before and during harvest, and that from noninfested floricanes was similar.

Received for publication 23 Oct. 1995. Accepted for publication 10 May 1996. Pacific Agriculture Research Centre (Vancouver) Manuscript no. 404206. We gratefully acknowledge the assistance of M. Bernard, S. Bubra, C. Cirkony, S. Lum Min, P. Smyth, and E. Walsh in conducting the field work, and H. Daubeny and S. Fitzpatrick for reviewing the manuscript. The work was supported in part by the Lower Mainland Horticultural Improvement Association, the B.C. Raspberry Growers' Association, the Federal Challenge Program, and Energy Mines and Resources Canada (PERD). The cost of publishing this paper was defrayed in part by the payment of page charges. Under postal regulations, this paper therefore must be hereby marked advertisement solely to indicate this fact.
Tetranychus urticae can completely defoliate primocanes in commercial fields after harvest. The objective of our study was to determine the effect of primocane defoliation on primocane diameter, lateral length, yield, and four yield components. Regulating mite infestations in a replicated experiment to obtain different levels of defoliation is very difficult in the field. We, therefore, used defoliation by hand to simulate mite damage. This kind of damage is instantaneous compared with mite-induced defoliation, which proceeds over the course of several weeks. The effect of hand defoliation on a given date may, therefore, be less severe than mite-induced defoliation around the same date because leaves removed by hand are fully functional until defoliation, whereas mites cause reductions in photosynthesis before defoliation (Cameron et al., 1990). Two studies were conducted, one in 1989-90 and one in 1992-93. The first study determined the impact of defoliation when the plant's resources were reduced to six primocanes soon after harvest. The second determined the impact when floricanes and excess primocanes were removed after the primocanes were fully dormant in November.

\section{Materials and Methods}

Fifty stools (plants) of 2-year-old 'Willamette' red raspberry located at Abbotsford, B.C. (lat. $49^{\circ} \mathrm{N}$, long. $122^{\circ} \mathrm{W}$ ), were each pruned to six primocanes (and no floricanes) 3 Aug. and again 14 Sept. 1989. The remaining primocanes in a stool were defoliated $0 \%, 25 \%, 50 \%, 75 \%$, or $100 \% 3$ Aug. or 14 Sept. 1989. These 10 treatments were replicated five times in a randomized complete-block design. Leaves were removed over the entire cane; for example, every other leaf was removed for the $50 \%$ treatment. Primocane diameter at $15 \mathrm{~cm}$ was measured 23 Jan. 1990. Two canes were selected at random from each replication 10 May, the laterals were counted, and lateral length was determined by averaging the lengths of a lower, middle, and upper lateral. The fruit were harvested, counted, and weighed two or three times per week from 25 June to 6 Aug. 1990.

The experiment was repeated with defoliation on 7 Aug. and 11 Sept. 1992. In this experiment, however, the floricanes and all but eight primocanes were removed in November when they were dormant. Furthermore, all the primocanes were defoliated in sections of various lengths from the lowest leaf to $2 \mathrm{~m}$ aboveground. The design was complicated by the natural loss of leaves from the primocanes, but it simulated, to a greater degree than the previous experiment, defoliation from mite damage, which tends to move upward from the leaves nearest the ground. Lengths of primocanes from which leaves were removed were $0,46,92$, and $138 \mathrm{~cm}$ on 7 Aug. and 0, 23, 46, 69, and $92 \mathrm{~cm}$ on 11 Sept. The number of laterals in each replication was counted 9 June 1993. The fruit were harvested, counted, and weighed two or three times per week from 23 June to 26 July.

Maintenance of the planting during these studies followed standard commercial practice (British Columbia Ministry of Agriculture Fisheries and Food, 1988): residual herbicide in March; fertilizer in March and May; and chemical primocane suppression in April. The data were analyzed by analysis of variance (ANOVA) and regression using SAS GLM and REG (SAS Institute, 1985). The ANOVA model was defoliation level $(X)$, time of defoliation $(T)$, blocks, and the interaction $X T$. Standard errors were based on the residual mean square from this model. Regression involved both forward selection and backward elimination of defoliation level $(X: \geq 0, \leq 1), X^{2}$, $X^{3}, X^{4}, X^{5}$; time of defoliation ( $T: 1$ or 2 ); and the interaction $X T ; P<0.05)$. The number of canes per stool was expressed as a proportion of the original total and transformed to degrees by arcsin square root. Regression of $\ln$ (variance) on $\ln ($ mean) for the remaining variables (Southwood, 1966) indicated that transformation of the data was not necessary, except for number of fruit per lateral in 1990, which required a reciprocal transformation.

\section{Results and Discussion}

In the 1989-90 experiment, the number of canes per stool, cane diameter, number of laterals per cane, lateral length, number of fruit per lateral, weight per fruit, and yield (number and weight) were affected by defoliation (Fig. 1). Three interactions between time and degree of defoliation were detected. While there was no loss of canes with increasing defoliation in September, there was increasing loss of canes with increasing defoliation in August (Fig. 1A), and while the number of laterals per cane decreased and the number of 

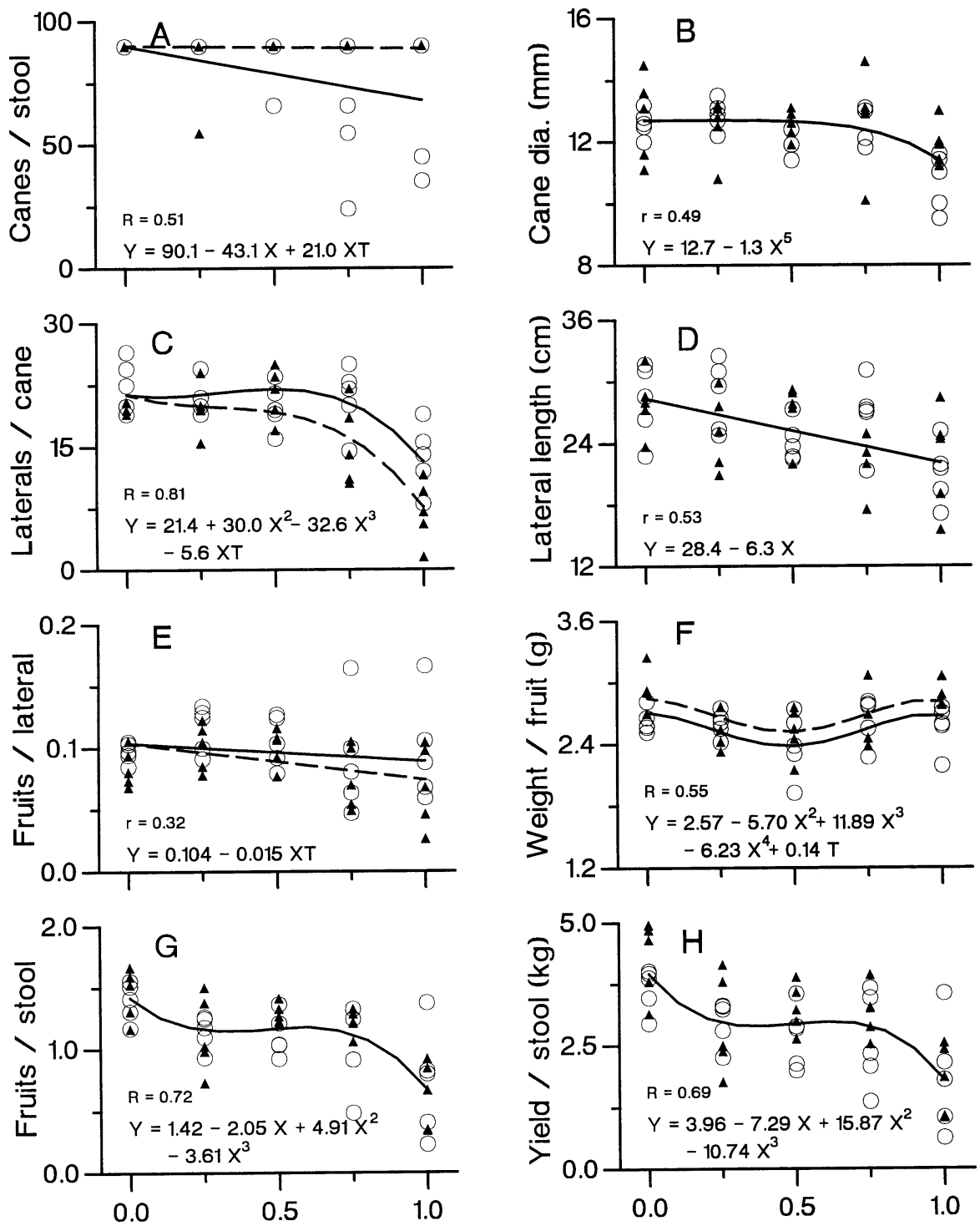

Primocane defoliation (proportion)

Fig. 1. Effect of primocane defoliation $(X)$ on growth and yield of 'Willamette' red raspberry. Defoliation is expressed as the proportion of leaves removed. The time of defoliation (T: 1 or 2) was 3 Aug. (circles and solid line) and 14 Sept. (triangles and dashed line) 1989. The number of canes per stool (A) was expressed as a proportion of the initial number in 1989 and transformed by arcsin square root to degrees The number of fruit per lateral $(\mathbf{E})$ required a reciprocal transform to stabilize the variance. All regressions were significant at $P<0.01$, except fruit per lateral $(\mathbf{E})$, at $P=0.02$.

fruit per lateral increased with increasing defoliation in August, the response was greater with defoliation in September (Fig. $1 \mathrm{C}$ and E). Weight per fruit was higher with defoliation in September as opposed to August (Fig. 1F). Here, the interaction term was not significant, so the equation provides a different weight per fruit for the two defoliation times when no leaves are removed-a result that is not correct. Despite the effect of defoliation time on these variables, no effect on yield was detected (Fig. $1 \mathrm{G}$ and $\mathrm{H}$ ).

Yield (kilograms) was reduced $26 \%$ at $25 \%, 50 \%$, and $75 \%$ defoliation and $55 \%$ at full defoliation compared with nondefoliated controls (Table 1). This result is consistent with the negative effect of defoliation on the number of canes per stool (August defoliation), cane diameter, number of laterals per cane, and lateral length (Fig. 1). The impact of increasing defoliation also was indicated by increased variation in the number of fruit per lateral [standard deviations at $0 \%, 25 \%, 50 \%$, $75 \%$, and $100 \%$ defoliation were $1.8,1.8,1.8$, 5.1, and $9.3(\mathrm{n}=10)]$.

Despite the negative impact of defoliation, the plant exhibited resilience; yield at $50 \%$ and $75 \%$ defoliation was similar to that at $25 \%$ defoliation (Fig. 1H). This effect can be partially explained by the regressions of the plant characteristics and components of yield against degree of defoliation. The regressions for the number of canes per stool (after back-transformation; Fig. 1A), cane diameter (Fig. 1B), and the number of laterals per cane (Fig. 1C) were nonlinear, such that the impact of defoliation was reduced at intermediate levels, and was most severe at full defoliation. The plant's capacity to make positive adjustments in yield at high levels of defoliation was indicated by the "U"-shaped relationship for weight per fruit (Fig. 1F) and by increased number of fruit per lateral at higher defoliation levels (after back-transformation; Fig. 1E).

The first experiment clearly indicates that primocane defoliation can result in reduced lateral production, concurring with Doughty et al. (1972). Waister and Barritt (1980) observed that when all buds on $50 \%$ of the nodes were removed at the beginning of the growing season, yield was only reduced by $30 \%$. Most of the compensation in yield was attributed to increased number of fruit per lateral. Although similar compensation was observed in our study, the yield reduction between zero and full defoliation was equal to the reduction in the number of laterals per stool $(55 \%)$. Full primocane defoliation then has a greater impact on the plant than bud removal in the spring, reducing the plant's yield-regulating ability.

In the 1992-93 experiment, only one significant relationship emerged $(Y=85.0-21.2$ $X^{5} ; r=0.60 ; P \leq 0.01$; where $Y$ is the number of canes per stool and $X$ is the proportion of defoliation on 7 Aug. 1992). Given the results of the 1989-90 experiment, a significant reduction in yield of $\approx 55 \%$ was expected between zero and full defoliation in August. However, yields for these two treatments were 3.4 and $2.9 \mathrm{~kg}$, respectively; the natural variation between replications with respect to yield was similar in both experiments (Table 1), so the ability to detect differences was the same. Processes at the level of the plant may have differed among experiments because the number of laterals per cane was lower $(t=15.0 ; P$ $<0.01)$ and weight per fruit was higher $(t=6.4$; $P<0.01)$ in 1993 than that recorded at zero defoliation in 1990 (Table 1). Several factors, including winter severity, could have caused the differing results in the two experiments; however, one factor that was clearly different was the timing of pruning of floricanes and excess primocanes. Allowing these canes to continue growing until dormancy in the 199293 experiment rather than pruning them in August may have reduced the impact of defoliation.

The interaction between winter severity and mite-induced defoliation of primocanes is an important factor affecting yield components (Doughty et al., 1972). The influence of winter conditions on the plant was not evaluated in our study. However, given the fact that winter severity cannot be reliably predicted, it would be prudent for growers to control $T$. urticae populations before mite-induced defoliation occurs.

\section{Literature Cited}

British Columbia Ministry of Agriculture Fisheries and Food. 1988. Berry production guide for commercial growers. British Columbia Ministry of Agriculture Fisheries and Food, Canada.

Cameron, J.S., C.A. Hartley, C.H. Shanks, Jr., and J.K.L. Garth. 1990. Effect of two-spotted spider mite feeding on gas exchange and chlorophyll characteristics of red raspberry leaves. HortScience 25:1166. 


\section{Crop Production}

Table 1. Average ( \pm SE) values of two plant characteristics (cane diameter and lateral length), yield, and four yield components in 1990 and 1993 for a range of primocane defoliation levels in 'Willamette' red raspberry in 1989 and 1992, respectively.

\begin{tabular}{|c|c|c|c|c|c|c|c|c|}
\hline \multirow[b]{2}{*}{$\begin{array}{l}\text { Defoliation } \\
\text { (proportion) }\end{array}$} & \multicolumn{2}{|c|}{ Canes } & \multicolumn{2}{|c|}{ Laterals } & \multicolumn{4}{|c|}{ Fruit } \\
\hline & $\begin{array}{c}\text { No./ } \\
\text { stool }^{2}\end{array}$ & $\begin{array}{l}\text { Diam } \\
(\mathrm{mm})\end{array}$ & $\begin{array}{l}\text { No./ } \\
\text { cane }\end{array}$ & $\begin{array}{c}\text { Length } \\
(\mathrm{cm})\end{array}$ & $\begin{array}{l}1 /(\text { no./ } \\
\text { lateral })^{y}\end{array}$ & $\begin{array}{c}\text { Wt/fruit } \\
(\mathrm{g})\end{array}$ & $\begin{array}{c}\text { No./ } \\
\text { stool }^{\mathrm{x}}\end{array}$ & $\begin{array}{c}\text { Yield/stool } \\
(\mathrm{kg})\end{array}$ \\
\hline \multicolumn{9}{|c|}{3 Aug. 1989} \\
\hline 0 & 90.0 & 12.6 & 22.5 & 28.1 & 0.097 & 2.63 & 1.39 & 3.66 \\
\hline 0.25 & 90.0 & 12.9 & 21.8 & 28.7 & 0.116 & 2.60 & 1.14 & 2.98 \\
\hline 0.5 & 85.2 & 12.1 & 19.9 & 24.2 & 0.105 & 2.39 & 1.11 & 2.68 \\
\hline 0.75 & 64.9 & 12.6 & 20.9 & 26.8 & 0.091 & 2.64 & 0.98 & 2.58 \\
\hline 1.0 & 70.1 & 10.7 & 13.7 & 21.0 & 0.097 & 2.56 & 0.72 & 1.83 \\
\hline \multicolumn{9}{|c|}{14 Sept. 1989} \\
\hline 0 & 90.0 & 12.8 & 20.0 & 27.9 & 0.084 & 2.94 & 1.45 & 4.28 \\
\hline 0.25 & 82.9 & 12.5 & 19.7 & 25.2 & 0.101 & 2.56 & 1.12 & 2.92 \\
\hline 0.5 & 90.0 & 12.6 & 21.4 & 27.1 & 0.100 & 2.52 & 1.29 & 3.26 \\
\hline 0.75 & 90.0 & 12.7 & 15.2 & 21.0 & 0.075 & 2.59 & 1.22 & 3.17 \\
\hline 1.0 & 90.0 & 11.9 & 7.0 & 22.4 & 0.068 & 2.91 & 0.62 & 1.78 \\
\hline $\mathrm{SE}^{\mathrm{w}}$ & 6.4 & 0.4 & 1.5 & 1.4 & 0.011 & 0.09 & 0.11 & 0.33 \\
\hline \multicolumn{9}{|c|}{ Pooled data for all levels and times of defoliation in 1992} \\
\hline & 81.2 & --- & 11.6 & --- & 11.5 & 3.25 & 1.01 & 3.28 \\
\hline $\mathrm{SE}^{\mathrm{v}}$ & 1.8 & --- & 0.2 & --- & 0.3 & 0.03 & 0.03 & 0.10 \\
\hline
\end{tabular}

${ }^{2}$ Canes per stool, expressed as a proportion of the original number at defoliation (six in 1989 and eight in 1992), and transformed by arcsin square root to degrees.

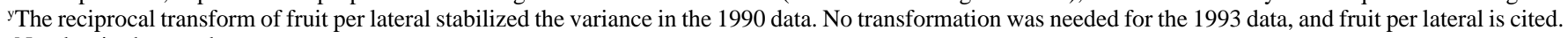

${ }^{\mathrm{x}}$ Number in thousands.

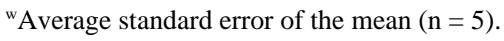

${ }^{\mathrm{v}}$ Average standard error of the mean $(\mathrm{n}=50)$.

Crandall, P.C., D.F. Allmendinger, J.D. Chamberlain, and K.A. Biderbost. 1974. Influence of cane number and diameter, irrigation, and carbohydrate reserves on the fruit number of red raspberries. J. Amer. Soc. Hort. Sci. 99:524526.

Doughty, C.C., P.C. Crandall, and C.H. Shanks, Jr. 1972. Cold injury to red raspberries and the effect of premature defoliation and mite damage. J. Amer. Soc. Hort. Sci. 97:670-673.
Jennings, D.L., E. Carmichael, and J.J. Costin. 1972. Variation in the time of acclimation of raspberry canes in Scotland and Ireland and its significance for hardiness. Hort. Res. 12:187-200.

Moore, P.P. 1994. Yield compensation of red raspberry following primary bud removal. HortScience 29:701.

Raworth, D.A. 1989. Towards the establishment of an economic threshold for the twospotted spider mite,Tetranychusurticae (Acari: Tetranychidae) on red raspberry, Rubus idaeus. Acta Hort. 262:223-226.

SAS Institute. 1985. SAS user's guide: Basics and statistics. version 5 ed. SAS Inst., Cary, N.C.

Southwood, T.R.E. 1966. Ecological methods with particular reference to the study of insect populations. Methuen \& Co., London.

Waister,P.D. and B.H. Barritt. 1980. Compensation in fruit numbers following loss of lateral buds in the red raspberry. Hort. Res. 20:25-31. 